\title{
Why are Patients with Acute Middle Cerebral Artery Infarction Being Intubated?
}

\author{
Akut Orta Serebral Arter Infarktı Olan Bir Hasta Neden Entübe Olur?
}

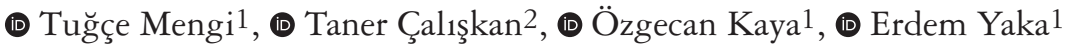 \\ 1Dokuz Eylul University Faculty of Medicine, Department of Neurology, Izmir, Turkey \\ 2Dokuz Eylul University Faculty of Medicine, Department of Anesthesiology and Reanimation, Izmir, Turkey
}

\begin{abstract}
Objective: To describe the causes of intubation in patients who have been diagnosed with middle cerebral artery (MCA) infarction requiring mechanical ventilation (MV) by evaluating the clinical and radiologic features in the neurological intensive care unit (NICU).

Materials and Methods: The patients with MCA infarction who required MV in the NICU were evaluated retrospectively. All patients' age, sex, risk factors of stroke, lesion topography, etiology and treatment of stroke, cause of intubation, percentage of extubation, death/discharge status were recorded.

Results: It is found that between June 1 15t, 2009, and December 31 st , 2015, 91 patients with stroke with MCA infarction were mechanically ventilated in the NICU. Fifty patients were intubated with neurologic causes and 40 patients needed intubation due to cardiopulmonary problems. One patient was treated in the NICU after surgery for a diaphragmatic hernia.

Conclusion: The patients with MCA infarction who are followed up on a mechanical ventilator have poor prognosis. This group of patients constitutes elderly individuals who are at risk for vascular and organ failure. Their follow-up must be conducted in NICUs.
\end{abstract}

Keywords: Ischemic stroke, mechanical ventilation, middle cerebral artery, neurological intensive care unit

$\ddot{O} \mathbf{z}$

Amaç: Nöroloji yoğun bakım ünitesinde (NYBÜ) mekanik ventilasyon (MV) gerektiren orta serebral arter (OSA) infarktı tanısı alan hastaların klinik ve radyolojik özelliklerini de ğerlendirerek entübe olma nedenlerinin tanımlanması amaçlanmıştır.

Gereç ve Yöntem: NYBÜ’de MV gerektiren OSA infarktlı hastalar retrospektif olarak değerlendirildi. Tüm hastaların yaşı, cinsiyeti, inme risk faktörleri, lezyon topografisi, inmenin etiyolojisi, tedavisi, entübasyon nedeni, ekstübasyon yüzdesi, ölüm/taburculuk hali kaydedildi.

Bulgular: 01.06.2009-31.12.2015 tarihleri arasında NYBÜ’de 91 OSA infarktı hastasına MV uygulandığ1 saptandı. Elli hastanın nörolojik nedenlerle ve 40 hastanın kardiyopulmoner nedenlerle entübe edildiği tespit edildi. Bir hastanın da diyafragma hernisine yönelik operasyon sonrası NYBÜ'de izlendiği saptandı. Sonuç: MV'de izlenen OSA enfarktı olan hastaların prognozu kötüdür. Bu hasta grubunu, vasküler ve organ yetmezlikleri açısından riskler taşıyan ileri yaşta bireyler oluşturur. Takiplerinin NYBÜ’lerde yapılması gereklidir.

Anahtar Kelimeler: İskemik inme, mekanik ventilasyon, orta serebral arter, nöroloji yoğun bakım ünitesi

\section{Introduction}

Functional disorders and complications in the respiratory system following acute ischemic stroke can be life-threatening (1). Complications such as chest wall and diaphragm function abnormalities, abnormal breathing patterns, sleep respiratory disturbances, pulmonary embolism, dysphagia, aspiration, pneumonia and neurogenic pulmonary edema may develop depending on the location and size of cerebral infarction (2), and patients with these complications can need mechanical ventilation (MV).

MV is required in $16 \%$ of patients with acute ischemic stroke (3). This value increases to $23.5 \%$ in patients with acute ischemic stroke in neurological intensive care units (NICUs) and stroke

Address for Correspondence/Yazışma Adresi: Tuğçe Mengi MD, Dokuz Eylul University Faculty of Medicine, Department of Neurology, Izmir, Turkey Phone: +90 5354614200 E-mail: tugceangin@gmail.com ORCID ID: orcid.org/0000-0002-0639-0957

Received/Geliş Tarihi: 01.05.2017 Accepted/Kabul Tarihi: 11.08.2017

${ }^{\circ}$ Copyright 2018 by Turkish Neurological Society

Turkish Journal of Neurology published by Galenos Publishing House. 
units (4). In a study conducted by Berrouschot et al. (5) with 218 patients with acute middle cerebral artery (MCA) infarction who were followed up in the NICU, $24 \%$ of patients were shown to require MV. Patients with MCA infarction underwent MV because of impaired consciousness, inadequate respiratory tract protection, affected neuronal networks that control respiration due to brain stem compression or lung damage due to aspiration and pneumonia, severe cardiac insufficiency along with pulmonary edema, and surgical and interventional endovascular treatments $(4,5,6)$.

The aim of the present study was to determine the causes of intubation by evaluating the clinical and radiologic characteristics of patients with MCA infarction who underwent MV and were treated in the NICU.

\section{Materials and Methods}

The study population consisted of patients with ischemic stroke who were treated in the NICU between June 1st, 2009, and December 31st, 2015. Ethics committee approval was obtained from Dokuz Eylul University Ethics Committee (Ethics Committee Approval number: 2017/04-18, date: 02.03.2017). Patients who were admitted to our hospital within the first three days after the onset of symptoms; who were diagnosed as having acute MCA infarction with anamnesis, clinical findings, and radiological examinations; and who were intubated and had invasive MV support in the emergency service, stroke unit, NICU or before the surgical/interventional endovascular treatment were included in the study. Patients who had primary intracerebral hemorrhage, who were treated with non-invasive MV support, who had acute infarction other than MCA territory, and who received care in other ICUs after intubation were not included in the study.

The records in our database and data in the hospital automation system of patients diagnosed as having MCA infarction were evaluated retrospectively. The age, sex, admission date to NICU, presence of smoking habit, past stroke, past transient ischemic attack, hypertension, diabetes mellitus, coronary artery disease, heart failure, atrial flutter or atrial fibrillation, chronic obstructive pulmonary disease and chronic renal failure were recorded on a data collection form. In addition, stroke symptoms, detailed neurologic examination, first Glasgow Coma Score (GCS), magnetic resonance imaging (MRI) and/or computed tomography (CT) results, and the affected branch of MCA were recorded. Investigations to determine the etiology of stroke (e.g., carotid Doppler ultrasonography, CT angiography, MR angiography, electrocardiography, echocardiography) were evaluated and the etiology of the patients were recorded according to the "Trial of Org 10172 in acute stroke treatment" classification. Intravenous thrombolytic therapy and/or endovascular interventional therapy, presence of progression in the post-treatment control brain CT, presence of progression in follow-up brain CT scans of patients with worsening neurologic examinations during clinical followup, and whether decompression surgery was performed in these patients were carefully studied.

All patients were assessed in detail for intubation. The number of days between stroke onset and intubation, the place of intubation (NICU or emergency service), the cause of intubation, pre-intubation GCS, pre-intubation chest X-ray findings, and whether the patient was extubated were recorded on the data collection form. Finally, mortality rates were determined.

\section{Results}

In our NICU, 223 patients with acute ischemic stroke received treatment between June 1st, 2009, and December 31st, 2015. Seventy-four percent of these patients (166/223) were found to have invasive MV support. It was found that 125 of 223 patients had acute MCA infarction, 91 of whom were intubated before admission to the NICU or during the follow-up in NICU.

This study included 91 patients, 36 males (39.6\%) and 55 females $(60.4 \%)$ aged between 46 and 93 years, with MCA infarction and MV support. The mean age was $74.6 \pm 10.47$ (mean \pm SD) years. Of the 91 patients, $72(79.1 \%)$ were aged over 65 years.

The distribution of comorbidities and stroke risk factors of patients with MCA infarction receiving MV support is shown in Table 1.

Regarding the neuroimaging studies performed in the emergency service, it was found that $40(45.1 \%)$ had only brain CT, and 50 patients $(54.9 \%)$ had diffusion MRI and brain CT scans. It was detected that conventional MRIs of patients were completed as in-service follow-ups. Parenchymal hypodensity was not detected in the MCA territory in the initial brain CT in 15 patients (16.5\%) who were thought to have MCA infarction according to clinical and neuroimaging results. Infarction was observed in the superior division in $11(12.1 \%)$ patients, in the inferior division in $8(8.8 \%)$ patients, and in the perforating branches of the MCA in 7 patients. In 30 (33\%) patients, infarction was detected in the area suggesting multiple branch involvement. Of $91 \mathrm{MCA}$ infarctions, 20 (22\%) had total MCA infarction. Fifty $(56 \%)$ patients had right MCA infarction, and $40(44 \%)$ patients had left MCA infarction. Twenty-three (25.3\%) patients had progression determined by clinical and/or neuroimaging during follow-up.

As a result of examinations to determine the etiology of stroke, large artery atherosclerosis was found in 15 (16.5\%) patients, cardioembolic stroke in $34(37.4 \%)$ patients, and unknown stroke in $24(26.4 \%)$ patients.

\begin{tabular}{|ll|}
\hline $\begin{array}{l}\text { Table 1. Distribution of stroke patients with middle } \\
\text { cerebral artery infarction in terms of stroke risk factors and } \\
\text { comorbidities }\end{array}$ & $\mathbf{n}(\%)$ \\
\hline $\begin{array}{l}\text { Hypertension } \\
\text { Diabetes mellitus }\end{array}$ & $77(84.6)$ \\
Heart failure & $29(31.9)$ \\
Coronary artery disease & $30(33.0)$ \\
Atrial flutter or atrial fibrillation & $23(25.3)$ \\
Chronic obstructive pulmonary disease & $56(61.5)$ \\
Chronic renal failure & $9(9.9)$ \\
Smoking & $7(7.7)$ \\
$\begin{array}{l}\text { Previous ischemic stroke and/or transient } \\
\text { ischemic attack }\end{array}$ & $13(14.3)$ \\
\hline
\end{tabular}


Twenty-four (26.4\%) patients were treated with only intravenous thrombolytic therapy, $9(9.9 \%)$ patients with endovascular interventional therapy, and $8(8.8 \%)$ patients with decompression surgery.

Regarding pre-intubation chest X-ray findings, three patients $(3.3 \%)$ had atelectasis, three patients $(3.3 \%)$ had effusion, 40 $(44 \%)$ patients had infiltration, one $(1.1 \%)$ patient had effusion and atelectasis, and three $(3.3 \%)$ patients had infiltration and effusion. Forty-one patients $(45.4 \%)$ had no significant pathology on chest X-ray that could cause respiratory distress.

Regarding pre-intubation control brain CTs, subfalcine herniation was present in $36(39.6 \%)$ patients, and hemorrhagic component was present in $19(20.9 \%)$ patients.

The mean admission GCS of the patients in the emergency service was $11.5 \pm 2.78$ (minimum: 3 , maximum: 15 ). On the day of intubation, the mean GCS of the patients was $8.9 \pm 3.57$ (minimum: 3, maximum: 15). Patients were intubated after a mean of $8.7 \pm 8.89$ days (minimum: 1 , maximum: 42 days) following the onset of stroke symptoms.

The causes of intubation of patients with MCA infarction are shown in Table 2; the most common causes were cardiopulmonary causes $(54.9 \%)$.

Of the 91 patients treated with MV, 29 (31.9\%) patients were found to be extubated due to meeting extubation parameters; 12 of whom were re-intubated because of MV need during ICU follow-up.

The mortality rate of 91 patients followed-up with invasive MV in the NICU was $67 \%$ (61/91). Of the 30 surviving patients, 17 were discharged from the NICU with spontaneous breathing, 11 with home ventilator, and 2 with a tracheotomy cannula. No mortality was observed during the NICU follow-up among 34 patients with acute MCA infarction who did not receive invasive MV support during the same period.

\begin{tabular}{|lc|}
\hline $\begin{array}{l}\text { Table 2. Causes of intubation in patients } \\
\text { cerebral artery infarction }\end{array}$ & w $(\%)$ \\
\hline Diaphragmatic hernia surgery & $1(1.1)$ \\
Cardiopulmonary causes & $50(54.9)$ \\
Pneumonia & $33(36.3)$ \\
Acute decompensated heart failure & $5(5.5)$ \\
Respiratory arrest or cardiac arrest & $5(5.5)$ \\
Pulmonary embolism & $2(2.2)$ \\
Aspiration & $2(2.2)$ \\
Acute respiratory distress syndrome & $1(1.1)$ \\
Alveolar hemorrhage & $1(1.1)$ \\
Atelectasis & $1(1.1)$ \\
Neurologic causes & $40(44.0)$ \\
${ }^{*}$ GCS $\leq 8$, emergency department & $6(6.6)$ \\
Endovascular interventional therapy or & $11(12.1)$ \\
decompression surgery & \\
Neurologic progression, ${ }^{\dagger}$ NICU & $23(25.3)$ \\
${ }^{*}$ GCS: Glasgow Coma Scale, ${ }^{\dagger}$ NICU: Neurology intensive care unit \\
\hline
\end{tabular}

\section{Discussion}

The MV requirement of patients with acute ischemic stroke ranges from $16-24 \%$ in the literature $(3,4)$. In our study, the intubation rate of patients with acute ischemic stroke was $74 \%$. This rate is quite high compared with other studies. The reasons for this situation are;

1) Inclusion of patients with acute ischemic stroke who were treated in the NICU and exclusion of patients treated in the stroke unit or neurology service, and,

2) Inclusion of patients who had undergone decompression surgery and were followed-up in the ICU.

The mortality rate of patients with MCA infarction who received MV support in NICU in our study was $67 \%$. In a study conducted by Santoli et al. (4) in patients with stroke receiving MV support, the 45 -day mortality rate was $63.8 \%$ and the 12 -month mortality rate was $72.4 \%$. In a study by Milhaud et al. (1), the 1 -year mortality rate was $70 \%$ in patients with MCA infarction who received MV support. The mean age of the patients in our study was $74.6 \pm 10.47$ years. Seventy-nine percent of the patients were aged over 65 years. Studies have indicated that prognosis is worse if patients with stroke need MV. Age over 65 years was found to be an independent predictor of 2-month mortality in patients with stroke requiring MV support (7).

MV was most commonly performed due to cardiopulmonary causes $(54.9 \%)$ in our study. The second most frequent cause $(23.5 \%)$ was progression on neurologic examination. Considering the fact that 6 patients were intubated for GCS $\leq 8$ in the emergency service and 11 patients were intubated due to endovascular interventional therapy or decompression surgery, neurologic causes of intubation increased to $44 \%$. Intubation due to neurologic deterioration in MCA infarctions was found as $90 \%$ in the study by Berrouschot et al. (5) and $86 \%$ in the study by Milhaud et al. (1). However, Berrouschot et al. (5) reported that patients who were included in the study were intubated after $29 \pm 27$ hours (4-120 hours) from the onset of stroke symptoms. In our study, this period was $8.7 \pm 8.89$ days ( 1 to 42 days), longer than the period detected by Berrouschot et al. (5). Given the progression of ischemic stroke in the acute phase, it is not surprising that cardiopulmonary causes are the most common cause of intubation that occurs during longer follow-up periods.

There is a close relationship between neurologic status and respiration in patients with large MCA infarcts (1). Neurologic deterioration causes a reduction in the protection of the upper airway, and also cerebral edema due to infarction affects the brainstem respiratory centers, leading to hypoventilation, intrapulmonary shunt, hypoxemia, and hypercarbia (1). Studies have reported that $50-60 \%$ of patients with stroke have hypoxia, and hypoxia has been reported in all of those with cardiac and pulmonary diseases (8). The resulting hypoxia increases cerebral ischemia and causes secondary neurologic damage (1).

The decrease in protection of the upper airway may be due to an absence or decrease in gag, swallowing, and cough reflexes. This causes aspiration and the inability to clear pulmonary secretions $(1,5)$. In our study, $39 \%$ of patients were given MV support because of aspiration and pneumonia. Of course, the absence of gag, swallowing and cough reflexes is not the only cause of pneumonia, but these are conditions that contribute to the development of pneumonia. 
Promising results of early thrombolytic therapy for acute ischemic stroke have increased interest in optimized medical care for ischemic stroke. Improving the cerebral perfusion of the penumbra through medical precautions in patients with stroke improves prognosis. This includes increased intracranial pressure management (anti-edema agents, hyperventilation or decompression surgery) as well as close arterial pressure and electrolyte balance monitoring (9). In our study, 24 (26.4\%) patients were treated with only intravenous thrombolytic therapy and 9 patients (9.9\%) with endovascular interventional therapy. Decompression surgery was performed in $8(8.8 \%)$ of patients.

The effects of posterior circulation infarctions on respiration are well known. However, in a number of studies on stroke and MV, similar to our study, MCA infarction was stated to be a more common cause $(3,10)$. Of the 166 patients intubated because of acute ischemic stroke in our study, $91(54.8 \%)$ were found to have acute MCA infarction.

In our study, 29 of 91 patients (31.9\%) were extubated because they met extubation parameters. Extubation can be considered in the event of adequate oxygenation, cardiovascular stability, elimination of the main cause of respiratory insufficiency, and if the patient can initiate first respiration without support (11). However, classic extubation criteria (including vital capacity, minute volume, maximum inspiratory pressure, rapid superficial breathing index) were inadequate to predict extubation failures in patients in the NICU (11). It is very important that neurologists monitor this patient group because more specific parameters are needed for successful extubation (such as the components of the GCS scoring) in patients with MCA infarction. However, this study does not address parameters that assess the success of extubation; a study is planned in the NICU for this subject.

\section{Conclusion}

In conclusion, this study has shown that patients with MCA infarction need close follow-up in the stroke unit and NICU for neurologic progression and cardiopulmonary decompensation and require timely and effective MV support. Our data represent the first retrospective data of patients with ischemic stroke in intensive care units in our country. Accordingly, we think that our findings will be useful in terms of determining the frequency of MV application, the underlying causes, mortality and morbidity in patients with ischemic stroke and promoting prospective multicenter studies.

\section{Ethics}

Ethics Committee Approval: Ethics Committee Approval was obtained from Dokuz Eylul University Ethics Committee (Ethics committee approval number: 2017/04-18, date: 02.03.2017).

Informed Consent: Retrospective study.

Peer-review: Externally and internally peer-reviewed.

\section{Authorship Contributions}

Surgical and Medical Practices: E.Y., Concept: T.Ç., Design: Ö.K., Data Collection or Processing: T.Ç., Ö.K., Analysis or Interpretation: E.Y., Literature Search: T.M., Writing: T.M.

Conflict of Interest: No conflict of interest was declared by the authors.

Financial Disclosure: The authors declared that this study received no financial support.

\section{References}

1. Milhaud D, Popp J, Thouvenot E, Heroum C, Bonafé A. Mechanical ventilation in ischemic stroke. J Stroke Cerebrovasc Dis 2004;13:183-188.

2. Güler A, Turgut N, Topaktaş S, Topçuoğlu MA, Şirin H, Kocaman AS, Kutluk K, Uzuner N. Komplikasyonların tedavisi ve yoğun bakım. Türk Beyin Damar Hastalıkları Derneği İnme Tanı ve Tedavi Kılavuzu - 2015. Türk Beyin Damar Hast Derg 2015;21:153-160.

3. Leker RR, Ben-Hur T. Prognostic factors in artificially ventilated stroke patients. J Neurol Sci 2000;176:83-87.

4. Santoli F, De Jonghe B, Hayon J, Tran B, Piperaud M, Merrer J, Outin H. Mechanical ventilation in patients with acute ischemic stroke: survival and outcome at one year. Intensive Care Med 2001;27:1141-1146.

5. Berrouschot J, Rössler A, Köster J, Schneider D. Mechanical ventilation in patients with hemispheric ischemic stroke. Crit Care Med 2000;28:29562961.

6. Froehler MT, Fifi JT, Majid A, Bhatt A, Ouyang M, McDonagh DL. Anesthesia for endovascular treatment of acute ischemic stroke. Neurology 2012;79(Suppl 1):167-173.

7. Foerch C, Kessler KR, Steckel DA, Steinmetz H, Sitzer M. Survival and quality of life outcome after mechanical ventilation in elderly stroke patients. J Neurol Neurosurg Psychiatry 2004;75:988-993.

8. Topçuoğlu MA, Utku U, İnce B, Özdemir AÖ, Baş DF, Kutluk K, Uzuner $\mathrm{N}$. İnme ünitesinde genel inme tedavisi. Türk Beyin Damar Hastalıkları Derneği İnme Tanı ve Tedavi Kılavuzu - 2015. Türk Beyin Damar Hast Derg 2015;21:89-92.

9. Steiner T, Mendoza G, De Georgia M, Schellinger P, Holle R, Hacke W. Prognosis of stroke patients requiring mechanical ventilation in a neurological critical care unit. Stroke 1997;28:711-715.

10. Qutub HO. Ischemic strokes requiring mechanical ventilation in the Intensive Care Unit. Neurosciences (Riyadh) 2001;6:103-105.

11. Wendell LC, Raser J, Kasner S, Park S. Predictors of extubation success in patients with middle cerebral artery acute ischemic stroke. Stroke Res Treat 2011;2011:248789. 